\title{
Corona Virus Prevention
}

\section{Dana Churchill*}

The Churchill Center, Functional Medicine, United States

*Corresponding Author: Dana Churchill, The Churchill Center, Functional Medicine, United States.

How to stay safe with the virus popping up all over the place: Keep your immunity strong so your body can fight it if necessary, takes several steps!

1. Wash hands often and use alcohol wipes. Bleach surfaces.

2. Use a mask if going into a crowded area.

3. Eat a lot of fresh fruit and steamed or raw veg. All organic. Drink unsweetened juices. Eat grapefruits everyday.

4. Eat more healthy protein (grass fed and no drugs or chemicals and, for fish - no farm raised fish- Wild Alaskan salmon has a lot of EPA and DHA to decrease inflammation).

5. Don't eat sugar, wheat/gluten or dairy, except for full fat yogurt, and any other foods you have a sensitivity or an allergy they will decrease your immunity.

6. Drink 2 liters of purified water every day.

7. Get plenty of rest 7 - 8 hours good sleep per night, (we can test epi-genetically to see why you can't do this).

8. Go easy on the caffeine or best none at all, it will spike cortisol and decreases immunity. At least trade coffee drinks for teas, especially green tea.

9. Alcohol: 1 glass of red wine every other day is ok or only on weekends, too much of this is bad for liver and will decrease immunity.

10. Do not ingest any marijuana this is one of the worst immune system down-regulators!

11. Some food that kill viruses: Raw garlic, Ginger, Turmeric, Green Tea. Licorice, Olive leaf, Elderberry, Capsicums

Essential oils in diffusers: Thieves essential oil from Young Living, was used to prevent the Bubonic plague, have 2 - 3 diffusers going in house at all times.

\section{Prevention therapies:}

IV therapy:

1. Vitamin C (has been tested in China and works well treating the Corona Virus).

2. Ozone IVs: Kills all microbes including Lyme disease which is harder to kill that any. Virus!

3. Colloidal Silver IVs.
4. Recovery/Performance IVs.

5. Hydrogen peroxide IVs.

6. Nutraceuticals/Botanicals: NT Factor Multi Immune, ACS Sliver, Good mushroom formula: Reishi, Maiatake Cordyceps, Coriolus, Shiitake, Curcumin, Good fish oil, Probiomax Complete or Probiomax Plus. Dr. Churchill's Anti-microbial tincture, Astragalus. Vit C, Vit D, Vit A (no pregnant, or nursing women or anyone wanting to get pregnant).

7. Peptides: Thymosin alpha 1, Thymosin Beta 4, LL37.

8. MSC Cord blood Stem cells and exosomes have been used in China successfully to treat the virus.

9. Dr. Churchills Super food Immune smoothie Dry ingredients.

10. Constitutional Hydrotherapy!

\section{Assets from publication with us}

- Prompt Acknowledgement after receiving the article

- Thorough Double blinded peer review

- Rapid Publication

- Issue of Publication Certificate

- High visibility of your Published work

Website: www.actascientific.com/

Submit Article: $w$ ww.actascientific.com/submission.php Email us: editor@actascientific.com

Contact us: +919182824667 